Historic, Archive Document

Do not assume content reflects current scientific knowledge, policies, or practices. 



\title{
Pachysandra to Benefit Your Old Trees
}

Pachysandra is used and strongly advocated by prominent Landscape Architects and Arborists to promote health and growth in aged or undernourished trees by furnishing ideal forest conditions.

Before planting the barren soil under the trees is heavily enriched with rotted manure and Peat Moss, which is a soil-building material capable of retaining sixteen times its weight of moisture.

The closely planted Pachysandra, forming an evergreen cover, prevents evaporation of moisture, keeps the soil from becoming hard and solid, shades the root system of the tree perfectly. The falling leaves are allowed to remain among the Pachysandra, as they are not seen, to furnish added humus.

Manure may be added from time to time without objection.

Is it any wonder observing men qualify its use and allow me to quote them, gladly?

This plant and many others for ground-cover use, I grow in great quantity at especially low prices to encourage you to use them.

Also garden-pottery and garden-wares of many kinds. Catalogs upon request.

\author{
HUGH B. BARCLAY \\ Grower of Ground-Cover Plants \\ Narberth, Pa.
}

ALSO

Garden Pottery and Garden Wares of many kinds

CATALOG UPON REQUEST 



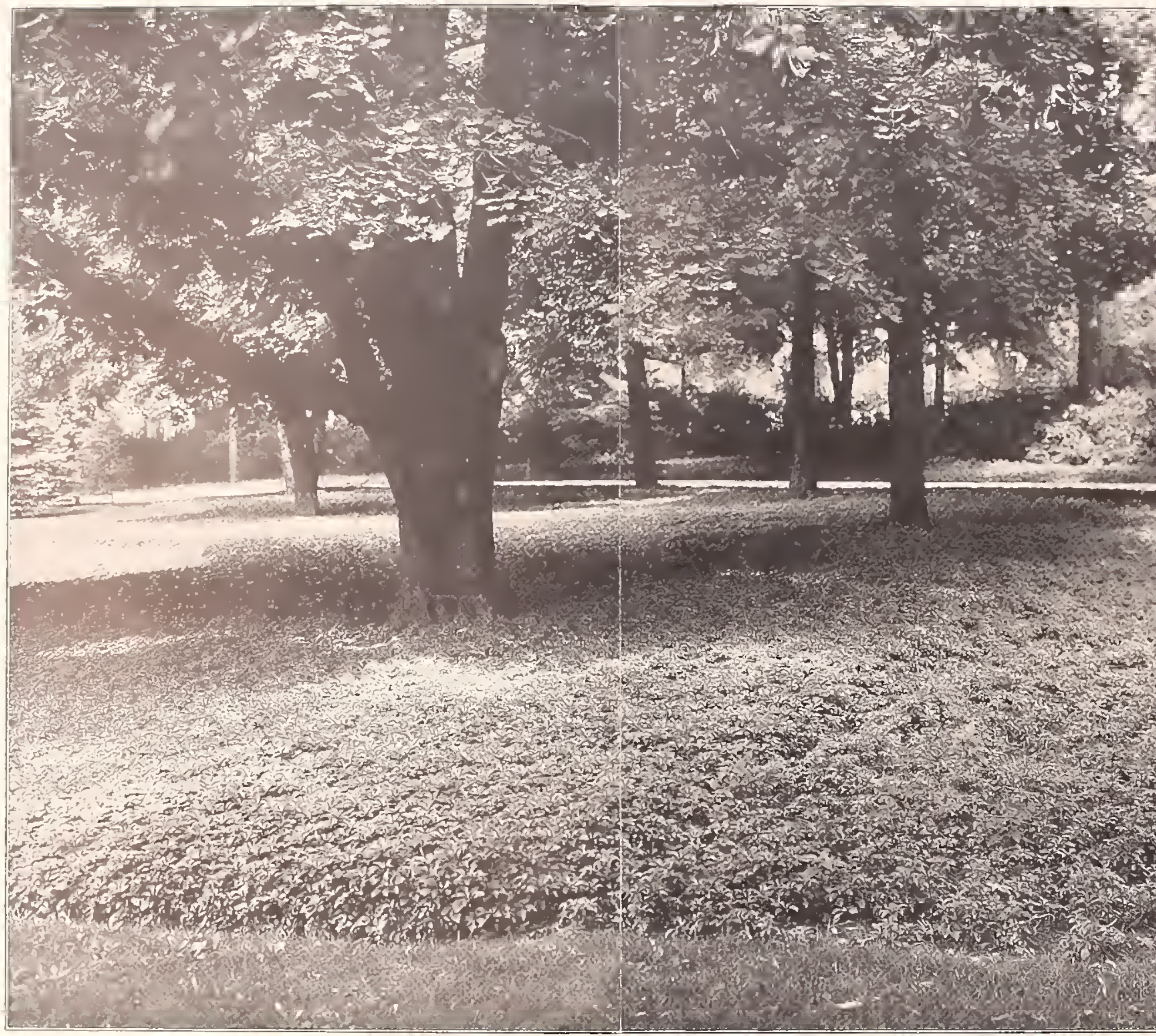

Pachysandra and Trees, both receiving ideal conditions for growth.

HUGH B. BARCLAY, Grower, Narberth, Pa, 


\section{BEAUTIFY AND BENEFIT WITH PACHYSANDRA}

\section{These are the opinions of some of the most prom- inent landscape architects in America:}

"I am of the opinion that Pachysandra is of immense benefit planted as a Ground Cover under old trees, and I know of numerous occasions where it has been so used in the vicinity of Boston."

"I am strong for the planting of Pachysandra and other Ground Covers about the base of old trees."

"It seems to me that the beneficial effect of Pachysandra on many trees would be almost a foregone conclusion."

"I am of the opinion that Pachysandra under trees on the lawn, where it is impossible to maintain good turf, not only prevents erosion, but maintains the moisture and is a decided benefit for both trees and shrubbery."

"In addition to its attractive appearance we find it a great aid in maintaining certain soil conditions and highly recommend its use in the restoration and preservation of old or undernourished trees."

"After applying topsoil, peat moss and manure, it is my intention to blanket these areas with Pachysandra, which I consider the most effective Ground Cover obtainable."

"My own experience has been that there is no better way of keeping a soil condition conducive to good root growth than by means of such a Ground Cover."

"We have been using Pachysandra for a number of years and find it a very desirable Ground Cover for use under trees."

"I am very much in favor of using the Ground Covers wherever possible in place of grass."

"Briefly I believe that its greatest value is that of continuing or reproducing forest conditions for old trees." 